Arab World English Journal (AWEJ) Volume 12. Number2 June 2021

Pp.3-21

DOI: https://dx.doi.org/10.24093/awej/vol12no2.1

\title{
Investigating Competency-Based Learning Implementation at the Northern Border University (NBU): A Descriptive Analytical Study
}

\section{Osama H. S. Hassanein}

Faculty of Education \& Arts, Curriculum \& Instruction Department Northern Border University (NBU), the Kingdom of Saudi Arabia

E-mail: u_zedan555@yahoo.com

Received: $1 / 14 / 2021$

Accepted:4/6/2021

Published: 6/24/2021

\begin{abstract}
Competency-Based Learning implementation has become a necessity at the Northern Border University (NBU), the kingdom of Saudi Arabia (KSA). However, there are still a lot of implementation challenges that need to be faced. In an attempt to overcome some of these challenges, this study conducted to identify the awareness level of competency-based learning among EFL faculty and to assess the extent to which faculty teaching practices, as well as EFL course descriptions, are supportive to competency-based learning at the NBU? The descriptiveanalytical method was used in this study. The study sample included all faculty members (both male \& female) teaching English as a Foreign Language (EFL) at the NBU during the academic year 2020-2021. To achieve the objectives of this study, a self-report questionnaire was used to elicit information about NBU faculty awareness level of competency-based learning. The questionnaire was also used to assess faculty views regarding their teaching practices and regarding EFL course descriptions used. Descriptive statistics were used in the present study. Results showed that overall awareness level of competency-based learning among NBU faculty is medium. Results also showed that the teaching practices of EFL faculty at the NBU, concerning all elements of competency-based learning are generally low and do not support competency-based learning. Moreover, results showed that course descriptions used at the NBU do not support competency-based learning. In light of these results, educational implications and some recommendations for raising faculty awareness of competency-based learning and for competency-based course design were discussed.
\end{abstract}

Keywords: Competency, competency-based learning, competency-based curriculum, Northern Border University

Cite as: Hassanein, O. H. S. (2021). Investigating Competency-Based Learning Implementation at the Northern Border University (NBU): A Descriptive Analytical Study. Arab World English Journal, 12 (2) 3-21.

DOI: https://dx.doi.org/10.24093/awej/vol12no2.1 


\section{Introduction}

It is commonly agreed that education is a crucial factor that influences one's situation in the labor market upon graduation. Education prepares learners for future occupations by equipping them with required skills. Yet, with the rapid appearance and creation of new jobs and occupations, nowadays, that need innovative knowledge and skills, it becomes difficult or even impossible for educational institutions, to cater for the increasing needs of the labor market (Małgorzata, Justyna, \& Michał, 2020; Ionescu, 2012). Supporting this, Gáthy (2013) puts it clear that "higher education usually does not meet the requirements of the labor market and, what is more, it actually contributes to the unemployment of young graduates" (cited in Varga, Szira, Bardos, \& Hajos, 2016, pp. 95-96). Furthermore, there is an extensively reported complaint among employers of the shortage in employees who are capable of transferring their acquired knowledge to solve work problems and make the proper decisions (Rodriguez \& Gallardo, 2017).

Accordingly, a shift is needed, in educational paradigms, from traditional time-based to outcome-based or competency-based which concentrates on the type of knowledge, skills, values and behaviors required for achieving the desired level of performance in a particular job or activity in the labor market. That shift which focuses on innovation in higher education, is one of the most important elements of the Saudi Arabian Kingdom's Vision 2030.

Despite the willingness on the part of universities, stakeholders, as well as employers, to implement competency-based learning, little is known about how to incorporate it into bachelor degree programs (Dragoo \& Barrows, 2016; Bosman \& Arumugam, 2019). Furthermore, there is a significant lack of peer-reviewed literature on CBL curriculum design (Torres, Brett, Cox \& Greller, 2018; Jennifer, Ellen \& Jessica, 2017; Ryan \& Cox, 2017). Hence, this study sought to investigate competency-based learning implementation at the NBU and the extent to which program study plans, as well as faculty teaching practices, support competency-based learning.

The study sought to answer the following question:

1. What is the level of awareness of competency-based learning among EFL faculty at the NBU?

2. To what extent do EFL faculty teaching practices support competency-based learning at the NBU?

3. To what extent do EFL course descriptions support competency-based learning at the NBU? The study sought to achieve the following objectives:

1. Identify the level of awareness of competency-based learning among EFL faculty at the NBU.

2. Identify the extent to which faculty teaching practices support competency-based learning at the NBU.

3. Identify the extent to which EFL course descriptions support competency-based learning at the NBU?

The significance of this study stems from the importance of its problem. Core competency research, as one of the most urgent research priorities at the NBU. Competencybased learning has become a crucial issue in university education. Policymakers, as well as those responsible for education, have come to agree the traditional time-based systems of education and ineffective teaching practices are to be replaced by a new and adequate educational paradigm that has the potential of lowering costs and help in graduating strong employable labor forces for 
the increasing requirements of the labor market. However, there are still many challenges in implementing competency-based learning that need to be tackled and this study is an attempt that potentially contribute to overcome these challenges.

\section{Literature Review}

\section{Competency-Based Learning}

With the change in higher education institutions, as required by the digitization of the society, from being centers of "knowledge dissemination to the core of forming specific competencies " that individuals need for their professional, as well as their social lives, competency-based learning has become a necessity nowadays (Kostikova, Viediernikova, Holubnycha, \& Miasoiedova, 2019, p. 118). Competency-based learning, especially in postgraduate education, represents a change from a mainly time-based model to an outcomebased one which is concerned with the attainment of individual competencies that define the knowledge, skills and attitudes required by a particular specialty (Evan, et al., 2020). This method of instruction deviates from setting time limits, during which students are asked to learn a given amount of knowledge and allows students to proceed in learning at their own pace. Thus, the learning objective changes from attaining an increased quantity of knowledge which can be delivered along one semester or quarter, to making sure that students master pre-determined learning outcomes before advancing to the following level (Henri, Johnson, \& Nepal, 2017).

For Parson, Childs, \& Elzie (2018) competency-based learning has grown significantly as a method that clearly connects skills of a particular profession and its protocols to the curriculum. In competency-based curriculum design, choices are based on the knowledge, skills and attitudes students need to be proficient in their professions upon graduation. According to Johnstone \& Soares (2014), competency-based education is urgently required nowadays for two reasons; firstly, it reorients the process of education toward the established mastery and application of gained knowledge and skills in the real world outside the educational institutions. In so doing, a bridge is built between academics and employers that leads to a better understanding of the type of knowledge and skills required by students to succeed in workplaces in their real life. Furthermore, competency-based education offers a means for helping quality and affordability to be found side by side in higher education.

Competency-based learning, for Henri, et al. (2017), is "an outcome-based, studentcentered form of instruction" (p. 607). According to that system of instruction, students are allowed to proceed to more advanced tasks upon mastering the essential pre-determined requirements of knowledge and skills. McDonald (2018) claims that competency-based higher education can be attractive to students because it enables them to master, often at a speed that suits them, the competencies essentially required for future careers.

\section{Key Principles of Competency-Based Learning}

After reviewing relevant literature (Johnstone \& Soares, 2014; Kris \& Yvonne, 2014; Williams, Moser, Youngblood \& Singer 2015; Richard \& Bedard-Vorhees, 2016; Fowler, 2018; Parson, Childs, \& Elzie, 2018; McDonald, 2018; Sturgis \& Casey, 2018; Egbert \& Shahrokni, 2019; Ralf, et al., 2020; among others) key principles of competency-based learning are summarized below: 


\section{Focus is on Demonstrable Competencies}

Unlike traditional or outcomes-based education, the focus in competency-based learning is on the demonstration of mastery of pre-determined and identified specific competencies and skills (Parson, Childs, \& Elzie, 2018). The student is assumed "do" not just "know". These competencies should derive from societal needs analysis and reflect vocational central problems and essential knowledge and skills students need after graduation.

\section{From Credit to Competency-Based System}

In a competency-based learning system, students are allowed to progress forward at their own pace regardless of age, seat time or other students. Once a student demonstrates mastery of identified competencies and necessary skills, s/he is free to move ahead. Student demonstrated mastery of academic content is assessed against established benchmarks (McDonald, 2018).

\section{From Faculty to Student-Centered}

In a competency-based learning system, a radical change in the roles of both faculty and students is done. Faculty no longer serve as knowledge transmitters responsible for lecturing over a specified number of hours and weeks. Their roles change from that of "sages on the stages" to "guides on the sides." They work with their students as facilitators who lead discussions, guide their learning, answer their questions and help them apply the knowledge they acquire. On the other hand, student roles change from passive recipients to proactive knowledgeproducing ones (Egbert \& Shahrokni, 2019). Thanks to the practical reusable learning resources available any time when required, students in competency-based learning are responsible for their own learning and for moving forward toward mastery.

\section{From Traditional Grading to Ongoing Competency-Based Assessment}

Instead of being at set points in time throughout the academic year, assessment in a competency-based learning is a criterion-referenced ongoing process which is achieved via skillspecific rubrics. It aims to give students actual information on their progress towards mastery of target competencies and essential skills required to move ahead to the following study level (Fowler, 2018). Assessment in competency-based learning is a valid and reliable process that can take several forms.

\section{Personalized Learning via Faculty Availability}

In a competency-based learning system, students receive just-in-time differentiated help according to their needs and abilities. Faculty should be ready to step in when their individual students need help. Faculty work with struggling students individually and help them draw on their strengths to help them move forward (Ralf, et al., 2020). In so doing, they offer them personalized learning and equal opportunities to succeed. Faculty should not wait for students requesting for help. Moreover, faculty should be wholly aware of each individual student's progress.

\section{Transparency}

In competency-based learning, transparency is a fundamental principle. Target competencies and skills must be clear to the students from the very beginning. A clear definition of these competencies should be given to the students. They should know what they are expected to master and demonstrate. Also, they should know how to master these competencies and how 
their work for each competency will be assessed. To be aware of their progress towards mastery, a detailed rubric for each competency with its observable outcomes should be provided to the students. Moreover, students should understand well how the target competencies will benefit them in their future life after graduation (Sturgis \& Casey, 2018).

\section{Related Studies}

To connect this study with the work already done for attaining an overall relevance and purpose, a review of related studies is presented here:

Evan, et al. (2020) conducted a study that aimed to identify needs of the faculty to support the change to Competency-Based Medical Education (CBME) by using an online survey which was designed to collect data from faculty members about their knowledge of the principles of CBME and the famous evaluation methods. The survey was also designed to elicit information about barriers to the application of CBME in obstetrics and gynecology residency programs across Canada. Results showed that although CBME is considered a positive change by most faculty members, some knowledge gaps were there among faculty members about CBME. Results also showed that the most significant barriers to the application of CBME comprised a lack of training in assessment, financial inferences and time restrictions.

Using a mixture of qualitative and quantitative methods of data collection, the study of Małgorzata, et al. (2020) aimed to investigate and compare the opinions of employers and prospective employees on the required competencies of the possible labor market members. The study used interviews of recruiters (on behalf of potential employers) and a survey of university alumnae (prospective employees). Results of the study showed that both the Polish alumnae as well as the employers identify the shortages of professional competencies required in the labor market. Employers also believed that the alumnae are not well prepared to use the acquired theoretical knowledge in practice.

The study of Kostikova, et al. (2019) was done to investigate the impact of a competency-based learning model for foreign language teaching on the successful accomplishment of the first certificate in English. It was showed that competency-based approach to teaching a foreign language for specific purposes is the most relevant type. Using a mixed-methods approach Kabombwe and Mulenga (2019) investigated the implementation of the competency-based teaching and learning among history teachers in in Lusaka district, Zambia. Results of the study showed that $67 \%$ of the participants did not understand the concept of competency-based learning. Results also showed that teachers were not using competencybased approaches because of a lack of awareness and skills required for implementing competency-based approaches.

Torres, Brett, Cox and Greller (2018), in a qualitative case study, described how competency-based education was implemented in three areas in New Hampshire. Results of their study showed that despite the improvement achieved over six years at each area, competencybased education had not been wholly implemented as a result of many challenges among which were inertial, practical, regulating and political ones. Jennifer, et al. (2017) aimed to prove how competency-based courses could be designed and implemented, in traditional educational environments in both online and classroom-based courses. They conducted a case study of a 
competency-based learning 'introduction to psychology course' in a private university in the Western United States. The study offered two competency-based units; one of them was online and the other was in the classroom. Eleven undergraduate participants attended the online unit and 24 attended the classroom-based unit of the course. The course design was presented for both units, including intended learning outcomes, projects and score assignments, teaching methods, together with student and teacher reflections on the intended learning outcomes.

\section{Methods}

\section{Population and Sample}

The study population included all faculty members (both male \& female) teaching EFL, during the academic year 2020-2021, at the NBU, the Kingdom of Saudi Arabia. To reach valid and reliable conclusions, a random sample of 151 faculty was used in this study. After rejecting questionnaires with missing data and improperly answered ones, one hundred and six (106) questionnaire data entered for final analysis.

\section{Study Instruments}

After a thorough review of related studies as well as literature which was written on competency-based education (Evan, et al., 2020; Małgorzata, et al., 2020; Kostikova, et al., 2019; Torres, et al., 2018; Jennifer, et al., 2017; Ryan \& Cox, 2017; among others) a 46-item questionnaire, was prepared for identifying NBU faculty awareness level of competency-based learning as well as their views regarding their teaching practices and regarding EFL course descriptions. The questionnaire uses a five-point Likert scale system ranging from 1 to 5 (5= strongly agree, $4=$ agree, $3=$ neither agree nor disagree, $2=$ disagree and $1=$ strongly disagree). The maximum score on this scale is 230 , whereas the minimum score is 46 .

In this questionnaire, participants were asked to choose the option that actually expresses how much they agree or disagree with the different statements about competency-based learning. The questionnaire, in its final form, consisted of seven parts: awareness of CBL (items 1-10), progression through demonstration of mastery of competencies (items 11-14), personalized instruction (items 15-21), flexible assessment (items 22-25), improvement of skills and positive dispositions (holistic development) (items 26-32), transparency (items 33-37) and course description (items 38-46).

\section{Validity, Internal Consistency and Reliability of the Questionnaire Validity}

The questionnaire's validity was established by showing it to a jury of experts in the research area who made their comments regarding the statement of the questionnaire's items, its format and its suitability to the participants of this study. Keeping the feedback from the jury members in mind, statements that did not go well with the questionnaire's objectives were removed.

\section{The Internal Consistency}

The questionnaire was administered to a pilot sample consisting of 20 randomly selected faculty who did not participate in the sample of the study. The Pearson's Coefficient was used to find the correlation of each statement with the total degree of the dimension it represents utilizing the software Statistical Package for Social Science (SPSS): 
Table 1. The values of the correlation coefficients between each statement and the total degree of the dimension to which it belongs and the level of its significance. $(N=20)$

\begin{tabular}{|c|c|c|c|c|c|c|c|c|}
\hline \multicolumn{3}{|c|}{$\begin{array}{l}\text { First dimension: personalized } \\
\text { instruction }\end{array}$} & \multicolumn{3}{|c|}{$\begin{array}{l}\text { Second dimension: progression } \\
\text { through demonstration of } \\
\text { mastery of competencies }\end{array}$} & \multicolumn{3}{|c|}{$\begin{array}{l}\text { Third dimension: } \\
\text { faculty awareness of CBL }\end{array}$} \\
\hline $\begin{array}{l}\text { No. of } \\
\text { Items }\end{array}$ & Pearson & Sig, & $\begin{array}{l}\text { No. } \\
\text { of } \\
\text { Items }\end{array}$ & Pearson & Sig, & $\begin{array}{l}\text { No. } \\
\text { of } \\
\text { Items }\end{array}$ & Pearson & Sig, \\
\hline 1 & ${ }^{* *} .455$ & 0.01 & 11 & ${ }^{* *} .409$ & 0.01 & 15 & **.916 & 0.01 \\
\hline 2 & ${ }^{* *} .482$ & 0.01 & 12 & **.787 & 0.01 & 16 & **.330 & 0.01 \\
\hline 3 & **.711 & 0.01 & 13 & **.748 & 0.01 & 17 & ${ }^{* *} .822$ & 0.01 \\
\hline 4 & **.755 & 0.01 & 14 & **.746 & 0.01 & 18 & ${ }^{* *} .859$ & 0.01 \\
\hline 5 & **.738 & 0.01 & & & & 19 & ${ }^{* *} .838$ & 0.01 \\
\hline 6 & ${ }^{* *} .518$ & 0.01 & & & & 20 & ${ }^{* *} .834$ & 0.01 \\
\hline 7 & **.706 & 0.01 & & & & 21 & ${ }^{* *} .860$ & 0.01 \\
\hline 8 & **.709 & 0.01 & & & & & & \\
\hline 9 & $* * 730$ & 0.01 & & & & & & \\
\hline 10 & ** .770 & 0.01 & & & & & & \\
\hline \multicolumn{3}{|c|}{$\begin{array}{l}\text { Fourth dimension } \\
\text { flexible assessment }\end{array}$} & \multicolumn{3}{|c|}{$\begin{array}{c}\text { Fifth dimension: improvement } \\
\text { of skills and positive } \\
\text { dispositions ( holistic } \\
\text { development) }\end{array}$} & \multicolumn{3}{|c|}{ Sixth dimension: transparency } \\
\hline $\begin{array}{l}\text { No. of } \\
\text { Items }\end{array}$ & Pearson & Sig, & $\begin{array}{l}\text { No. } \\
\text { of } \\
\text { Items }\end{array}$ & Pearson & Sig, & $\begin{array}{l}\text { No. } \\
\text { of } \\
\text { Items }\end{array}$ & Pearson & Sig, \\
\hline 22 & **.773 & 0.01 & 26 & **.494 & 0.01 & 33 & **.799 & 0.01 \\
\hline 23 & ${ }^{* *} .772$ & 0.01 & 27 & ${ }^{* *} .675$ & 0.01 & 34 & **.391 & 0.01 \\
\hline 24 & **.684 & 0.01 & 28 & **.779 & 0.01 & 35 & ${ }^{* *} .882$ & 0.01 \\
\hline 25 & ${ }^{* *} .492$ & 0.01 & 29 & **.751 & 0.01 & 36 & ${ }^{* *} .884$ & 0.01 \\
\hline \multicolumn{3}{|c|}{$\begin{array}{l}\text { Seventh dimension: course } \\
\text { description }\end{array}$} & 30 & ${ }^{* *} .662$ & 0.01 & 37 & ${ }^{* *} .771$ & 0.01 \\
\hline $\begin{array}{l}\text { No. of } \\
\text { Items }\end{array}$ & Pearson & Sig, & 31 & ${ }^{* *} .776$ & 0.01 & & & \\
\hline 38 & **.766 & 0.01 & 32 & ** .382 & 0.01 & & & \\
\hline 39 & ${ }^{* *} .887$ & 0.01 & & & & & & \\
\hline 40 & ${ }^{* *} .875$ & 0.01 & & & & & & \\
\hline 41 & ${ }^{* *} .839$ & 0.01 & & & & & & \\
\hline 42 & **.902 & 0.01 & & & & & & \\
\hline 43 & ${ }^{* *} .790$ & 0.01 & & & & & & \\
\hline 44 & ${ }^{* *} .813$ & 0.01 & & & & & & \\
\hline 45 & ${ }^{* *} .710$ & 0.01 & & & & & & \\
\hline 46 & ${ }^{* *} .280$ & 0.01 & & & & & & \\
\hline
\end{tabular}

**. Correlation is significant at the 0.01 level (2-tailed).

It is evident from table one that the correlation coefficients of each statement with the total degree of the dimension it represents were all statistically significant at 0.01 level. This indicates that all the statements of the study questionnaire have an appropriate degree of internal consistency. This means that the questionnaire enjoys a high degree of internal consistency. 
The questionnaire's internal consistency was also assessed by calculating the correlation coefficient between the degree of each dimension and the total degree of the questionnaire as shown in the following table:

Table 2. The correlation coefficients between the dimensions of the questionnaire with each other and between them and the total degree of the questionnaire $(n=20)$.

\begin{tabular}{|c|c|c|c|c|c|c|c|c|}
\hline $\begin{array}{c}\text { Competency-based } \\
\text { learning }(\mathrm{CBL}) \\
\text { Items }\end{array}$ & 1 & 2 & 3 & 4 & 5 & 6 & 7 & Total \\
\hline $\begin{array}{l}\text { Faculty } \\
\text { awareness }\end{array}$ & 1 & & & & & & & \\
\hline $\begin{array}{l}\text { Progression } \\
\text { through } \\
\text { demonstration }\end{array}$ & $.804^{* *}$ & 1 & & & & & & \\
\hline $\begin{array}{l}\text { Personalized } \\
\text { instruction }\end{array}$ & $.898^{* *}$ & $.877^{* *}$ & 1 & & & & & \\
\hline $\begin{array}{l}\text { Flexible } \\
\text { assessment }\end{array}$ & $.849^{* *}$ & $.799^{* *}$ & $.869^{* *}$ & 1 & & & & \\
\hline $\begin{array}{l}\text { Improvement of } \\
\text { Skills }\end{array}$ & $.885^{* *}$ & $.895^{* *}$ & $.918^{* *}$ & $.877^{* *}$ & 1 & & & \\
\hline Transparency & $.877^{* *}$ & $.810^{* *}$ & $.926^{* *}$ & $.813^{* *}$ & $.915^{* *}$ & 1 & & \\
\hline $\begin{array}{l}\text { Course } \\
\text { description }\end{array}$ & $.843^{* *}$ & $.866^{* *}$ & $.936^{* *}$ & $.792^{* *}$ & $.892^{* *}$ & $.933^{* *}$ & 1 & \\
\hline Total Degree & $.940^{* *}$ & $.907^{* *}$ & $.977^{* *}$ & $.895^{* *}$ & $.961^{* *}$ & $.955^{* *}$ & $.956^{* *}$ & 1 \\
\hline
\end{tabular}

**. Correlation is significant at the 0.01 level (2-tailed).

It is clear from table two that the values of the correlation coefficients between the dimensions of the questionnaire and its total degree are high and statistically significant at 0.01 level. This affirms the availability of internal consistency in the questionnaire.

\section{Reliability}

The questionnaire's reliability was examined in two different ways: by using Cronbach's alpha coefficient and by using the Spearman-Brown formula.

Table 3. Reliability coefficients of the questionnaire's dimensions using the Cronbach's alpha coefficient and the Spearman-Brown formula.

\begin{tabular}{|l|c|c|c|}
\multicolumn{1}{|c|}{ Competency-based learning (CBL) Items } & $\begin{array}{c}\text { No. } \\
\text { of } \\
\text { Items }\end{array}$ & $\begin{array}{c}\text { Cronbach's Alpha } \\
\text { Bpearman- } \\
\text { Brown }\end{array}$ \\
\hline Faculty awareness & 10 & .837 & .935 \\
\hline Progression through Demonstration & 4 & .618 & .674 \\
\hline Personalized Instruction & 7 & .923 & .909 \\
\hline
\end{tabular}


Arab World English Journal (AWEJ) Volume 12. Number 2. June 2021

Investigating Competency-Based Learning Implementation

Hassanein

\begin{tabular}{|l|l|l|l|}
\hline Flexible Assessment & 4 & .525 & .539 \\
\hline Improvement of Skills & 7 & .624 & .790 \\
\hline Transparency & 5 & .699 & .747 \\
\hline Course Description & 9 & .866 & .920 \\
\hline Total Degree & 46 & .966 & .983 \\
\hline & & & \\
\hline
\end{tabular}

Table three shows that according to both Cronbach's alpha coefficient and Spearman-Brown formula, the reliability coefficient of the study questionnaire for all dimensions was more significant than the acceptable percentage. Besides, the reliability coefficient of the total score of the questionnaire was also superior than the required percentage. Overall reliability coefficient was 0.966 as calculated by Cronbach's alpha and 0.983 as calculated by Spearman-Brown's formula. This indicates that the study questionnaire enjoys reasonable reliability.

Participants' responses to this questionnaire were judged according to the following judgment criterion:

Table 4. The criterion for judging the responses of the study Participants

\begin{tabular}{cc} 
Mean Score & Acceptance Degree \\
$(1.00-1.79)$ & Very Low \\
$(1.80-2.59)$ & Low \\
$(2.60-3.39)$ & Medium/Moderate \\
$(3.40-4.19)$ & High \\
$(4.20-5.00)$ & Very High \\
\hline
\end{tabular}

\section{Results of the Study}

Results reached after data analysis are presented in this part. Descriptive statistics were used in this study by using the latest version of the software Statistical Package for Social Science (SPSS).

\section{Answer to the First Question}

As stated earlier in this study, the first question asked: 'what is the level of awareness of competency-based learning among EFL faculty at the NBU? To answer this question, participants' responses to the first dimension of the questionnaire are presented:

Table 5. Means and standard deviations of the responses of the study sample to the questionnaire's items in the dimension of faculty awareness of CBL.

\begin{tabular}{|c|c|c|c|c|c|}
\hline No. & Competency-based learning (CBL) Items & $\underset{8}{3}$ & 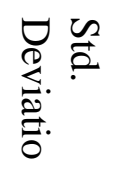 & 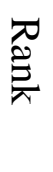 & Level \\
\hline 1 & $\begin{array}{l}\text { When talking about competencies we are referring } \\
\text { to the essential skills and knowledge a student } \\
\text { must learn to graduate not the required credits s/he } \\
\text { has to complete. }\end{array}$ & $\begin{array}{c}1.36 \\
8\end{array}$ & .622 & $\begin{array}{l}1 \\
0\end{array}$ & V. low \\
\hline 2 & $\begin{array}{l}\text { In CBL, emphasis is on measurable competencies } \\
\text { that help build students' skills for life. }\end{array}$ & $\begin{array}{c}1.94 \\
3\end{array}$ & 1.050 & 7 & Low \\
\hline
\end{tabular}




\begin{tabular}{|c|c|c|c|c|c|}
\hline 3 & $\begin{array}{l}\text { In CBL, course competencies must be specified } \\
\text { earlier and put as specific topics and activities that } \\
\text { constitute the learning objectives to be achieved by } \\
\text { each student. }\end{array}$ & $\begin{array}{c}4.28 \\
3\end{array}$ & .802 & 3 & High \\
\hline 4 & $\begin{array}{l}\text { Course competencies should be based on a } \\
\text { practical understanding of basic concepts, } \\
\text { knowledge application to real-life situations, and } \\
\text { mastery of related important skills. }\end{array}$ & $\begin{array}{c}4.60 \\
4\end{array}$ & .713 & 1 & V. high \\
\hline 5 & $\begin{array}{l}\text { In CBL, mastery of pre-determined learning } \\
\text { objectives and the way they will be measured } \\
\text { should be clear, not only for the faculty but also for } \\
\text { students from the Very beginning. }\end{array}$ & $\begin{array}{c}4.53 \\
8\end{array}$ & .679 & 2 & V. high \\
\hline 6 & $\begin{array}{l}\text { In CBL, graduation requirements prepare students } \\
\text { for what they want to do after graduation. }\end{array}$ & $\begin{array}{c}1.78 \\
3\end{array}$ & $\begin{array}{c}1.08 \\
7\end{array}$ & 9 & Low \\
\hline 7 & $\begin{array}{l}\text { In CBL, several opportunities should be given to } \\
\text { students to show their mastery of essential course } \\
\text { material. }\end{array}$ & $\begin{array}{c}3.98 \\
1\end{array}$ & .862 & 4 & High \\
\hline 8 & $\begin{array}{l}\text { In CBL, students can demonstrate their mastery of } \\
\text { each competency in several ways i.e., more than } \\
\text { one assignment, more than one assessment, or } \\
\text { more than one exam. }\end{array}$ & $\begin{array}{c}1.91 \\
5\end{array}$ & .782 & 8 & Low \\
\hline 9 & $\begin{array}{l}\text { In CBL, students can progress at their own } \\
\text { individual pace focusing on learning rather than on } \\
\text { the number of credits received or time spent for } \\
\text { passing courses. }\end{array}$ & $\begin{array}{c}3.79 \\
3\end{array}$ & 1.075 & 6 & High \\
\hline 10 & $\begin{array}{l}\text { In CBL, a competency-based grading system is } \\
\text { used instead of traditional grading. }\end{array}$ & $\begin{array}{c}3.96 \\
2\end{array}$ & 1.068 & 5 & High \\
\hline & Total & 3.217 & 0.874 & & $\begin{array}{l}\text { Mediu } \\
\text { m }\end{array}$ \\
\hline
\end{tabular}

Table five displays that the awareness level of competency-based learning among EFL faculty at the NBU is generally medium with an obtained mean score of 3.217 and with a standard deviation of 0.874 . The table shows that faculty at the NBU have a moderate level of awareness of competency-based learning with the knowledge that "competencies that should be based on a practical understanding of basic concepts, knowledge application to real-life situations and mastery of related important skills" being at the peak of their awareness (rank 1) and with the knowledge that "when talking about competencies we are referring to the essential skills and the knowledge a student must learn to graduate not the required credits s/he has to complete" being at the base of their awareness (rank 10).

\section{Answer to the Second Question}

As stated earlier in this study, the second question asked: 'to what extent do EFL faculty teaching practices support competency-based learning at the NBU? To answer this question, 
participants' responses to the second, third, fourth, fifth and sixth dimensions of the questionnaire are presented:

Table 6. Means and standard deviations of the responses of the study sample to the questionnaire's items in the dimension of progression through demonstration of mastery of competencies.

\begin{tabular}{|c|c|c|c|c|c|}
\hline $\begin{array}{c}\text { No } \\
\text {. }\end{array}$ & Competency-based learning (CBL) Items & $\begin{array}{l}3 \\
\stackrel{8}{8} \\
\cong\end{array}$ & 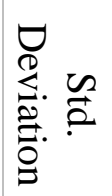 & $\begin{array}{l}\bar{\lambda} \\
\hat{ٍ} \\
\text { ह्र }\end{array}$ & Level \\
\hline 1 & $\begin{array}{l}\text { Through regular assessments of my students and by using } \\
\text { observational progress reports on learning, I can identify } \\
\text { where each student is. }\end{array}$ & $\begin{array}{c}2.84 \\
0\end{array}$ & $\begin{array}{c}1.21 \\
2\end{array}$ & 1 & Low \\
\hline 2 & $\begin{array}{l}\text { When a student demonstrates a clear understanding of the } \\
\text { material, proves his/her ability to apply that understanding } \\
\text { in real-life situations and shows how s/he developed } \\
\text { essential skills, s/he is allowed to move forward. }\end{array}$ & $\begin{array}{c}1.83 \\
9\end{array}$ & .826 & 4 & Low \\
\hline 3 & $\begin{array}{l}\text { A student is able to move on to the following competency } \\
\text { when s/he is ready even if other colleagues in the course } \\
\text { are not. }\end{array}$ & $\begin{array}{c}1.85 \\
9\end{array}$ & .761 & 3 & Low \\
\hline 4 & $\begin{array}{l}\text { In my classes, a student might work on numerous } \\
\text { competencies concurrently, when s/he masters one, s/he is } \\
\text { allowed to move to the following one. }\end{array}$ & $\begin{array}{c}1.99 \\
1\end{array}$ & .799 & 2 & Low \\
\hline \multicolumn{2}{|r|}{ Total } & $\begin{array}{c}2.13 \\
2\end{array}$ & $\begin{array}{c}0.90 \\
0\end{array}$ & & Low \\
\hline
\end{tabular}

Table six reveals that teaching practices of EFL faculty at the NBU, concerning progression through demonstration of mastery of competencies, are generally low with an obtained mean score of 2.132 and with a standard deviation of 0.900 . These practices as such do not support competency-based learning. The table shows that "identifying where each student is through regular assessment of students and by means of observational progress reports on learning" came at the top of their teaching practices (rank one) in this element of competency-based learning. On the other hand, "allowing a student to move forward when s/he demonstrates a clear understanding of the material, proves his/her ability to apply that understanding in real-life situations and shows how s/he developed essential skills" came as the least practiced (rank four) in this element.

Table 7. Means and standard deviations of the responses of the study sample to the questionnaire's items in the dimension of personalized instruction.

\begin{tabular}{|c|c|c|c|c|c|}
\hline No. & Competency-based learning (CBL) Items & $\begin{array}{l}3 \\
\stackrel{8}{8}\end{array}$ & 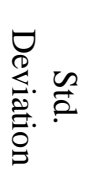 & 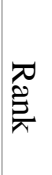 & Level \\
\hline 1 & In my classes, I teach my students and support them on the basis of & 1.849 & .790 & 7 & Low \\
\hline
\end{tabular}




\begin{tabular}{|c|c|c|c|c|c|}
\hline & $\begin{array}{l}\text { their individual strengths and weaknesses, and they are all } \\
\text { individually given the same chances to succeed. }\end{array}$ & & & & \\
\hline 2 & I usually work with my students individually or in small groups. & 2.915 & 1.220 & 1 & Medium \\
\hline 3 & In my classes, I am usually on the lookout for any request for help. & 1.906 & .775 & 5 & Low \\
\hline 4 & $\begin{array}{l}\text { In my classes, I do my best to identify my students' readiness needs } \\
\text { and address their individual learning styles and I use several } \\
\text { different techniques to teach the material. }\end{array}$ & 1.869 & .810 & 6 & Low \\
\hline 5 & $\begin{array}{l}\text { I discuss with each individual student in my class how s/he is doing } \\
\text { on each competency. }\end{array}$ & 1.962 & .804 & 2 & Low \\
\hline 6 & $\begin{array}{l}\text { I usually give each individual student in my class written feedback } \\
\text { on his/her work. }\end{array}$ & 1.925 & .777 & 3 & Low \\
\hline 7 & $\begin{array}{l}\text { I usually give each individual student in my class several } \\
\text { opportunities to choose how to show me what s/he has learned. }\end{array}$ & 1.916 & .823 & 4 & Low \\
\hline & Total & 2.049 & 0.857 & & Low \\
\hline
\end{tabular}

Table seven indicates that teaching practices of EFL faculty at the NBU, concerning personalized instruction, are generally low with an obtained mean score of 2.049 and with a standard deviation of 0.857 . These practices as such do not support competency-based learning. The table shows that "working with students individually or in small groups" came at the top of their teaching practices (rank one) in this element of competency-based learning. On the other hand, "teaching students and supporting them on the basis of their separate strengths and weaknesses and giving them all the same chances as individuals to succeed" came as the least practiced (rank seven) in this element.

Table 8. Means and standard deviations of the responses of the study sample to the questionnaire's items in the dimension of flexible assessment.

\begin{tabular}{|c|c|c|c|c|c|}
\hline No. & Competency-based learning (CBL) Items & $\underset{\Re}{\stackrel{3}{\sharp}}$ & 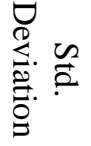 & 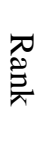 & Level \\
\hline 1 & $\begin{array}{l}\text { Assessment of my students could be formative to monitor their } \\
\text { learning and to have feedback that can be used for improving } \\
\text { teaching and learning. }\end{array}$ & 1.896 & .729 & 3 & Low \\
\hline 2 & $\begin{array}{l}\text { Assessment of my students could be authentic to demonstrate } \\
\text { mastery through asking students to apply their knowledge to real- } \\
\text { life situations. }\end{array}$ & 1.992 & .811 & 2 & Low \\
\hline 3 & $\begin{array}{l}\text { My students are allowed to demonstrate their mastery of each } \\
\text { course competency in several ways i.e., more than one }\end{array}$ & 1.764 & .799 & 4 & V. Low \\
\hline
\end{tabular}




\begin{tabular}{|c|l|c|c|c|c|}
\hline & assignment, more than one assessment, or more than one exam. & & \\
\hline 4 & $\begin{array}{l}\text { My students are given several opportunities to demonstrate } \\
\text { mastery of each course competency. }\end{array}$ & 2.830 & 1.215 & 1 & Medium \\
\hline Total & 2.121 & 2.461 & Low \\
\hline
\end{tabular}

Table eight indicates that teaching practices of EFL faculty at the NBU, concerning personalized instruction, are generally low with an obtained mean score of 2.121 and with a standard deviation of 2.461. These practices as such do not support competency-based learning. The table shows that "giving students several opportunities to demonstrate mastery of each course competency" came at the top of their teaching practices (rank one) in this element of competency-based learning. On the other hand, "allowing students to demonstrate their mastery of each course competency in several ways" came as the least practiced (rank four) in this element.

Table 9. Means and standard deviations of the responses of the study sample to the questionnaire's items in the dimension of improvement of skills and positive dispositions.

\begin{tabular}{|c|c|c|c|c|c|}
\hline No. & Competency-based learning (CBL) Items & $\underset{\S}{3}$ & 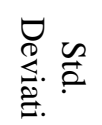 & থृ & Level \\
\hline 1 & I encourage my students to respect other people's feelings. & 3.321 & 1.284 & 2 & Medium \\
\hline 2 & $\begin{array}{l}\text { I explain to my students how to accept others and treat them with } \\
\text { respect, even when they're different from them or they disagree } \\
\text { with them. }\end{array}$ & 1.594 & .687 & 7 & V. Low \\
\hline 3 & $\begin{array}{l}\text { When a student in my class has difficulty in learning something, I } \\
\text { usually give him/her advice and offer him/her strategies that help } \\
\text { him/her to keep trying. }\end{array}$ & 1.745 & .744 & 3 & V. Low \\
\hline 4 & $\begin{array}{l}\text { I consistently encourage my students to take responsibility for } \\
\text { their learning. }\end{array}$ & 1.633 & .723 & 6 & V. Low \\
\hline 5 & $\begin{array}{l}\text { I consistently demonstrate explicit strategies to my students to use } \\
\text { anytime to help each other learn. }\end{array}$ & 1.679 & .711 & 5 & V. Low \\
\hline 6 & $\begin{array}{l}\text { I consistently demonstrate explicit strategies to my students that } \\
\text { they can use anytime to work together effectively in groups. }\end{array}$ & 1.726 & .737 & 4 & V. Low \\
\hline 7 & $\begin{array}{l}\text { I consistently encourage my students to help each other even after } \\
\text { class time and outside of the class. }\end{array}$ & 3.359 & 1.189 & 1 & Medium \\
\hline \multicolumn{2}{|r|}{ Total } & 2.151 & 0.868 & & Low \\
\hline
\end{tabular}

Table nine reveals that teaching practices of EFL faculty at the NBU, concerning improvement of skills and positive dispositions (holistic development), are generally low with an obtained mean score of 2.151 and with a standard deviation of 0.868 . These practices as such do not support competency-based learning. The table shows that "encouraging students to help each other even after class time and outside of the class" came at the top of their teaching practices Arab World English Journal 
(rank one) in this element of competency-based learning. On the other hand, "explaining to students how to accept others and treat them with respect, even when they are different from them or they disagree with them" came as the least practiced (rank seven) in this element. Table 10. Means and standard deviations of the responses of the study sample to the questionnaire's items in the dimension of transparency.

\begin{tabular}{|c|c|c|c|c|c|}
\hline $\begin{array}{c}\text { No } \\
\text {. }\end{array}$ & Competency-based learning (CBL) Items & $\begin{array}{l}3 \\
\stackrel{3}{0}\end{array}$ & 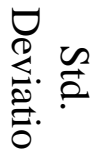 & 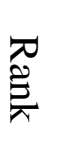 & Level \\
\hline 1 & $\begin{array}{l}\text { I consistently make clear pre-determined course } \\
\text { competencies and learning objectives to my students } \\
\text { from the very beginning. }\end{array}$ & $\begin{array}{c}1.66 \\
0\end{array}$ & .729 & 3 & $\begin{array}{l}\text { V. } \\
\text { Low }\end{array}$ \\
\hline 2 & $\begin{array}{l}\text { Mastery of course competencies is defined for students } \\
\text { from the very beginning. }\end{array}$ & $\begin{array}{c}3.42 \\
5\end{array}$ & $\begin{array}{c}1.21 \\
1\end{array}$ & 1 & High \\
\hline 3 & $\begin{array}{l}\text { I consistently inform my students and explain to them } \\
\text { how their work will be assessed for each course } \\
\text { competency. }\end{array}$ & $\begin{array}{c}1.65 \\
1\end{array}$ & .756 & 4 & $\begin{array}{l}\text { V. } \\
\text { Low }\end{array}$ \\
\hline 4 & $\begin{array}{l}\text { I consistently help my students understand how the } \\
\text { course competencies will help them in their future life } \\
\text { after graduation. }\end{array}$ & $\begin{array}{c}1.62 \\
3\end{array}$ & .736 & 5 & $\begin{array}{l}\text { V. } \\
\text { Low }\end{array}$ \\
\hline 5 & $\begin{array}{l}\text { I provide my students with a rubric to know how they } \\
\text { are progressing on each course competency. }\end{array}$ & $\begin{array}{c}1.67 \\
0\end{array}$ & .610 & 2 & $\begin{array}{l}\text { V. } \\
\text { Low }\end{array}$ \\
\hline \multicolumn{2}{|r|}{ Total } & $\begin{array}{c}2.00 \\
6\end{array}$ & $\begin{array}{c}0.82 \\
6\end{array}$ & & Low \\
\hline
\end{tabular}

Table 10 demonstrates that teaching practices of EFL faculty at the NBU, concerning improvement of skills and positive dispositions or holistic development, are generally low with an obtained mean score of 2.006 and with a standard deviation of 0.826 . These practices as such do not support competency-based learning. The table shows that "defining mastery of the course competencies for students from the very beginning" came at the top of their teaching practices (rank one) in this element of competency-based learning. On the other hand, "helping students to understand how the course competencies will help them in their future life after graduation" came as the least practiced (rank five) in this element.

Thus, the teaching practices of EFL faculty at the NBU, concerning all elements of competency-based learning are generally low. These practices as such do not support competency-based learning.

\section{Answer to the Third Question}

As stated earlier in this study, the third question asked: 'to what extent do EFL course descriptions support competency-based learning at the NBU? To answer this question, participants' responses to the seventh dimensions of the questionnaire are presented: 
Table 11. Means and standard deviations of the responses of the study sample to the questionnaire's items in the dimension of course description.

\begin{tabular}{|c|c|c|c|c|c|}
\hline No. & Competency-based learning (CBL) Items & $\begin{array}{l}3 \\
\stackrel{3}{3}\end{array}$ & 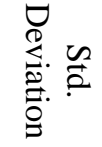 & 爷 & Level \\
\hline 1 & $\begin{array}{l}\text { Competencies around which the course was built were identified } \\
\text { through a partnership between NBU faculty and employers in the } \\
\text { labor market. }\end{array}$ & 1.670 & .740 & 5 & $\begin{array}{l}\text { V. } \\
\text { Low }\end{array}$ \\
\hline 2 & $\begin{array}{l}\text { The Course competencies are aligned with the NBU core } \\
\text { competencies. }\end{array}$ & 1.594 & .687 & 8 & $\begin{array}{l}\text { V. } \\
\text { Low }\end{array}$ \\
\hline 3 & $\begin{array}{l}\text { The Course competencies are broken down into specific } \\
\text { competencies or identified measurable skills, abilities and } \\
\text { qualifications students are expected to demonstrate. }\end{array}$ & 1.708 & .756 & 4 & $\begin{array}{l}\text { V. } \\
\text { Low }\end{array}$ \\
\hline 4 & $\begin{array}{l}\text { Prescribed learning activities with clear instructions help achieve } \\
\text { the course competencies and learning objectives. }\end{array}$ & 1.604 & .726 & 7 & $\begin{array}{l}\text { V. } \\
\text { Low }\end{array}$ \\
\hline 5 & $\begin{array}{l}\text { Links, if any, with other courses that contribute to developing the } \\
\text { same course competencies are clearly shown. }\end{array}$ & 1.576 & .690 & 9 & $\begin{array}{l}\text { V. } \\
\text { Low }\end{array}$ \\
\hline 6 & $\begin{array}{l}\text { Rigorous ongoing assessments with detailed rubrics are designed } \\
\text { specifically to measure students' mastery of each competency with } \\
\text { specific assessment criteria. }\end{array}$ & 1.736 & .772 & 2 & $\begin{array}{l}\text { V. } \\
\text { Low }\end{array}$ \\
\hline 7 & $\begin{array}{l}\text { Mastery requirements of each course competency are evidently } \\
\text { specified. }\end{array}$ & 1.604 & .687 & 6 & $\begin{array}{l}\text { V. } \\
\text { Low }\end{array}$ \\
\hline 8 & $\begin{array}{l}\text { Accessibility of learning resources, that supports the achievement } \\
\text { of the course competencies and learning objectives, whether on or } \\
\text { off-campus, is clearly described. }\end{array}$ & 1.718 & .756 & 3 & $\begin{array}{l}\text { V. } \\
\text { Low }\end{array}$ \\
\hline 9 & $\begin{array}{l}\text { Clear instructions on how and when to access the course faculty for } \\
\text { academic support are plainly provided. }\end{array}$ & 3.651 & 1.219 & 1 & High \\
\hline & Total & 1.873 & 0.781 & & Low \\
\hline
\end{tabular}

Table 11 shows that EFL faculty at the NBU consider course descriptions at the NBU are not supportive of competency-based learning. They rated them as being generally low with an obtained mean score of 1.873 and with a standard deviation of 0.781 . The table shows that "providing clear instructions on how and when to access the course faculty for academic support" was the most rated as supportive of competency-based learning by those faculty. It came at the first rank (rank one). On the other hand, "showing clear links, if any, with other courses that contribute to developing the same course competencies" was rated as the least supportive of competency-based learning (rank nine). 


\section{Discussion}

In general, this study attempted to identify EFL faculty awareness level of competencybased learning and the extent to which their teaching practices, as well as EFL course descriptions used, support competency-based education. Thus, the results and conclusion of this study are hoped to help in the adequate implementation of Competency-Based Learning at the NBU, the Kingdom of Saudi Arabia. As shown by the results of this study, the overall awareness level of competency-based learning among NBU faculty is medium. It seems that they had a shaky knowledge of competency-based learning. They failed to show a deeper understanding of the principles of competency-based learning. Their pedagogical beliefs seem to be oriented to the traditional fixed-time system of instruction. In this respect, Curry and Docherty (2017) put it clear that all of us aspire to have highly qualified graduates, equipped with innovative knowledge and competencies, capable of responding to the increasing needs of the labor market in a rapidly changing world. Yet, many of us struggle with the awareness, skills and attitudes required to define, identify, deliver, measure and modify those essential competencies across learning situations and into teaching professions. Therefore, competency-based learning forces us to change our accustomed pedagogical beliefs and behaviors.

This result is in line with the results of the study of Kafyulilo, Rugambuka and Moses (2012) which concluded that most teachers in Tanzania had difficulties in explaining some competency based concepts. This result also confirms the results of Kabombwe' and Mulenga's (2019) study which showed that most teachers surveyed were not conversant with what competency-based learning is.

Results also showed that the teaching practices of EFL faculty at the NBU, concerning all elements of competency-based learning are generally low. Their teaching practices as such do not support competency-based learning. They do not support any of the elements of competencybased learning mentioned in this study (progression through demonstration of mastery of competencies, personalized instruction, flexible assessment, holistic development and transparency). These results are consistent with those of Benjamin (2014) and Kabombwe and Mulenga (2019) which showed that most teachers seem not to implement competency-based learning approach and that they were still using teacher-centered methods compatible with the traditional content-based curriculum.

Keeping in mind the previous result, this result is an expected one. The teaching practices of NBU faculty are expected not to be supportive of competency-based learning as they showed shaky awareness of competency-based learning principles. This is not surprising since it is assumed that good performance is a result of good thought/knowledge (Curry \& Docherty, 2017). Supporting this, Kabombwe and Mulenga (2019) claim that a lack of knowledge of competency-based learning among teachers hinders successful implementation.

Results also showed that the course descriptions at the NBU do not support competencybased learning. They do not reflect particular specifications required for competency-based learning. For example, courses at the NBU were not built around specific competencies, identified through a partnership between NBU faculty and employers in the labor market and not adjusted to student learning needs. Besides, detailed rubrics required for rigorous ongoing 
assessments for measuring students' mastery of each competency were lacking in the course descriptions at the NBU.

In this respect, Curry and Docherty (2017) assure that competency-based learning study plans must be routinely designed and pre-learning assessments should be done in order for recognizing the knowledge and skills already possessed by students for minimizing the amount of time spent on areas already mastered. However, Simonds, Behrens and Holzbauer (2017) assert that there is lack of literature on competency-based course design because designing competency-based courses is highly time-consuming and labor-intensive.

\title{
Conclusion
}

Paving the way for adequate research-informed implementation of competency-based learning, this study was performed to investigate the awareness level of competency-based learning among EFL faculty and the extent to which their teaching practices, as well as EFL course descriptions used, support competency-based learning at the NBU, the Kingdom of Saudi Arabia. The overall awareness level of competency-based learning among NBU faculty proved medium and was reflected in their teaching practices. This indicates that those faculty are not sufficiently aware of the principles of competency-based learning. It is necessary, therefore, for the NBU to help raise the awareness of its faculty before embarking in the implementation of competency-based learning. This can be achieved through holding orientation seminars, awareness-raising meetings and training sessions for those faculty on the approaches of competency-based learning. Moreover, course descriptions used by scientific departments as such proved not to be supportive to competency-based learning therefore, a thorough review of program study plans and course design at the NBU is badly needed before implementing competency-based learning.

Further research, in needed to identify competencies required by students after graduation through a partnership with employers in the labor-market. More research is also needed to investigate the potential challenges of competency-based learning implementation at the NBU. Besides, further descriptive research is also need offer the practical ways of training faculty in competency-based approaches and competency-based course design.

\section{Acknowledgments}

The author extends his appreciation to the deputyship for Research \& Innovation, Ministry of Education in Saudi Arabia for funding this research work through the project number (77382020-IF).

\begin{abstract}
About the author
Prof. Osama H. S. Hassanein is a professor of applied linguistics and foreign language pedagogy in the Department of Curriculum and Instruction, Faculty of Education \& Arts, Northern Border University, the Kingdom of Saudi Arabia. Also, he works as the consultant to the rector of the Northern Borders University. His research focuses on developing foreign language skills, pragmatics, psycholinguistics (motivation), EFL instructional design and competency-based learning. ORCID ID: https://orcid.org/0000-0001-8171-0642
\end{abstract}




\section{References}

Benjamin, L. (2014). The Implementation of Constructivist Approach in Competency-Based Curriculum: A Case of Geography teaching in selected Secondary Schools in Songea Municipality, (Unpublished Master's Thesis). The Open University of Tanzania, United Republic of Tanzania.

Bosman, L., \& Arumugam, S. (2019). A Scaffold and Competency-Based Learning Approach to Innovation Related Thinking Frameworks. Proceedings of the ASEE Annual Conference \& Exposition, 393-2403.

Curry, L., \& Docherty, M. (2017). Implementing Competency-based Education. Collected Essays on Learning and Teaching, 10, 61-73. DOI: 10.22329/celt.v10i0.4716

Dragoo, A., \& Barrows, R. (2016). Implementing Competency-Based Education: Challenges, Strategies and a Decision-Making Framework. The Journal of Continuing Higher Education, 64(2), 73-83. DOI: 10.1080/07377363.2016.1172193

Egbert, J., \& Shahrokni, S. (2019). Balancing Old and New: Integrating Competency-Based Learning into CALL Teacher Education. The JALT CALL Journal, 15(1), 3-18. https://doi.org/10.29140/jaltcall.v15n1.156

Evan, T. et al. (2020). Exploring Faculty Perceptions of Competency-Based Medical Education and Assessing Needs for Implementation in Obstetrics and Gynaecology Residency. Journal of Obstetrics and Gynaecology Canada, 42(6), 707-717. DOI: https://doi.org/10.1016/j.jogc.2019.10.034

Fowler, A. (2018). Transitioning to Competency-Based Grading, (Unpublished Doctoral Dissertation). Carson-Newman University, Tennessee, United States.

Henri, M., Johnson, M., \& Nepal, B. (2017). A Review of Competency-Based Learning: Tools, Assessments and Recommendations. Journal of Engineering Education, 106(4), 607-638. DOI: $10.1007 / \mathrm{s} 40037-018-0481-2$

Ionescu, A. M. (2012). How does Education Affect Labor Market Outcomes? Review of Applied Socio-Economic Research, 4(2), 130-144.

Jennifer, S., Ellen, B., \& Jessica, H. (2017). Competency-Based Education in a Traditional Higher Education Setting: A Case Study of an Introduction to Psychology Course. International Journal of Teaching and Learning in Higher Education, 29(2), 412-428.

Johnstone, S. M., \& Soares, L. (2014). Principles for Developing Competency-Based Education Programs, Change: The Magazine of Higher Learning, 46(2), 12-19. DOI: 10.1080/00091383.2014.896705

Johnstone, S., \& Soares, L. (2014). Principles for developing competency-based education programs. Change: The Magazine of Higher Learning, 46(2), 12-19. DOI: 10.1080/00091383.2014.896705.

Kabombwe, Y., \& Mulenga, I. (2019). Implementation of the competency-based curriculum by teachers of History in selected Secondary Schools in Lusaka district, Zambia. Yesterday \& Today, (22), 19-41. DOI: http://dx.doi.org/10.17159/2223-0386/2019/n22a2

Kafyulilo, A, Rugambuka, I., \& Moses, I (2012). The implementation of competency based teaching approaches in Tanzania: The case of pre-service teachers at Morogoro teacher training college. Universal Journal of Education and General Studies, 1(11), 399-347.

Kostikova, I., Viediernikova, T., Holubnycha, L., \& Miasoiedova, S. (2019). The CompetencyBased Approach to Passing First Certificate in English. Revista Romaneasca pentru Educatie Multidimensionala, 11(1), 117-130. https://doi.org/10.18662/rrem/100 
Kris, C., \& Yvonne, S. (2014). College for America: Student-Centered, Competency-Based Education. Change: The Magazine of Higher Learning, 46(6), 613. DOI: $10.1080 / 00091383.2014 .969141$.

Małgorzata, G., Justyna, K., \& Michał, T. (2020). Competencies of graduates as future labor market participants - preliminary study. Economic Research-Ekonomska Istraživanja, 33(1), 1095-1107. DOI: 10.1080/1331677X.2019.1631200

McDonald, N. (2018). A Private, Nonprofit University's Experiences Designing a CompetencyBased Degree for Adult Learners. The Journal of Continuing Higher Education, 66, 3445. DOI: $10.1080 / 07377363.2018 .1415632$

Parson, L., Childs, B., \& Elzie, P. (2018). Using Competency-Based Curriculum Design to Createa Health Professions Education Certificate Program that Meets the Needs of Students, Administrators, Faculty and Patients. Health Professions Education, 4, 207217. DOI .org/10.1016/j.hpe.2018.03.008

Ralf, A. et al. (2020). Does Implementation of Competence-based Education Mediate the Impact of Team Learning on Student Satisfaction? Journal of Vocational Education \& Training, 72(4), 516-535. DOI: 10.1080/13636820.2019.1644364

Richard, A., \& Bedard-Vorhees, A. (2016). Principles for competency-based Education. In C. Reigeluth, et. al (Eds.), Instructional-Design Theories and Models, Volume IV: The Learner-Centered Paradigm of Education (pp. 33-64). New York, NY: Routledge.

Rodriguez, I., \& Gallardo, K. (2017). Redesigning an Educational Technology Course under a Competency-Based Performance Assessment Model. Pedagogika/Pedagogy, 127(3),186204. DOI: http://dx.doi.org/10.15823/p.2017.48

Ryan, S., \& Cox, J. (2017). Investigating student exposure to competency-based education. Education Policy Analysis Archives, 25(24), 1-

32. DOI: https://doi.org/10.14507/epaa.25.2792

Simonds, J., Behrens, E., \& Holzbauer, J. (2017). Competency-Based Education in a Traditional Higher Education Setting: A Case Study of an Introduction to Psychology Course. International Journal of Teaching and Learning in Higher Education, 29(2), 412-428.

Sturgis, C., \& Casey, K. (2018). Quality principles for competency-based education. Vienna, VA iNACOL. Retrieved from: https://aurora-institute.org/wp-content/uploads/QualityPrinciples-Book.pdf

Torres, A., Brett, J., Cox, J., \& Greller, S. (2018). Competency Education Implementation: Examining the Influence of Contextual Forces in Three New Hampshire Secondary Schools. AERA Open, 4(2), 1-13. DOI: 10.1177/2332858418782883

Varga, E., Szira, Z., Bardos, K., \& Hajos, L. (2016). The Most Relevant Labor Market Competencies for Employers and their Assessment by Students. Practice and Theory in Systems of Education,11(2), 95-104. DOI: 10.1515/ptse-2016-0012

Williams, M., Moser, T., Youngblood, J., \& Singer, M. (2015). Competency Based Learning: Proof of Professionalism. Academy of Business Journal, 2, 50-61. 